has let contracts for structures involving millions of dollars, and a failure to secure cement as needed, entering as it does so largely in the work, will be disastrous. Owing to the inaccessibility of many of the government works, the transportation of cement is difficult and costly. This was particularly the case in Salt River Valley in Arizona, where the great distance from existing mills and the expensive wagon haul made the cost prohibitive. After making thorough investigation of the cost of bringing in cement for the Roosevelt Dam and other structures, the government erected its own mill, and for several months past has been turning out daily hundreds of barrels of firstclass cement at a price far below the cost of cement shipped in. It is known that materials required for manufacturing cement of good quality exist near several of the other projects, and private parties should embrace the opportunity to go into the business. From the present outlook, however, the government seems to have a choice of shipping from the far eastern seaboard or from Europe, or of manufacturing its own cement.

\section{SOME FEATURES OF THE GREAT EARTHQUAKE.}

I was afforded an excellent opportunity to observe the effects of the great California earthquake of April 18,1906 , being in San José at the time of the shock Then, in about an hour, I left for San Francisco over the Southern Pacific Coast line, which traverses the west shore of San Francisco Bay from Palo Alto on the south to the center of the city on the north.

At San Bruno, fifteen miles south of San Francisco, the train was halted on account of damaged track, and the great majority of the passengers started on afoot. As for myself, I walked about twelve miles, when I was overtaken by the train which had finally managed to creep across the shaken track and proceed on its way.

I then went as far as the Valencia Street station, in the southern quarter of San Francisco. At that point I ascertained that it would be impossible to get through the city and across the bay to Oakland; and having started for the last-named point to learn the fate of my family, I concluded to turn back and proceed to San José, or wait at some small town on the peninsula until such time as I could make my way via San Francisco.

I walked back some five miles, and then took a train back to San José, arriving there at six o'clock P. M., just twelve hours from the time of my departure. Meantime I had traveled fifty miles of the worst-affected territory and returned.

I am of the opinion that when the relative force of the earthquake has been approximately measured, it will be found that the point of greatest energy was in the vicinity of San José. I am quite sure from my personal observations that the shock at San José was much more severe than that at San Francisco.

There is no point that apparently received so severe a - shock as San José and some of the smaller towns next north of it on the peninsula, excepting Santa Rosa, and that town is almost exactly the same distance north of San Francisco as San José is south. Thus San Francisco might be taken as the center of the disturbance, with a constantly-increasing force both north and south for distances of fifty miles, from whence outward the force constantly diminished.

Now as to the disturbance in an easterly and westerly direction: The next day I took a train for Oakland, on the east side of the bay, and was surprised to observe that that strip of country had been far less affected than the strip that I had traversed the day before. There were a few chimneys down along the route, and when I reached my home in Fruitvale, a suburb of Oakland on the southeast, there was hardly any evidence that an earthquake had struck the section the day before.

Of course, the effect westward of San Francisco could not be judged, because there is the boundless Pacific; and if there were any upheaval at all, it came in the shape of a tidal wave, and I have yet to hear that any such phenomenon occurred in that direction. Eastward still of Oakland there was a constantly d minishing tremor. Stockton, sixty miles inland from the Golden Gate, reported but a comparatively sligh disturbance. So there is the approximate area of the great terrestrial disturbance.

Now as to local effects. At the time of the shock I was in bed in a small room in the rear of the second floor of a large square-frame dwelling on North Thir Street, San José. I had wakened some fifteen minute before, and was trying to get one more nap before arising. Suddenly I was aroused from a half-slumber by the sound of a rush and a roar outside, and in second the whole house was swaying from side to side and straining in every part.

Then there was a momentary lull, after which came the supreme shock. The house appeared to heave up and down and sway from side to side at the same time, just as if it had been suddenly cast upon a roll- ing sea. The terrible force appeared to gain strength ontinually, and it seemed as if the whole structure would be wrenched in pieces and flung to the ground in a heap of ruins. In the meantime the roar outside had become almost deafening, and this was punctuated with crash after crash of falling buildings in distant parts of the town.

Then all was calm, and that calm was almost as terrifying as the storm that had just ended, for who could tell what was coming?

Upon rising I found my washstand, which had stood back against the east wall of the room, moved out from the wall at its south end about a foot, while all around the carpet was drenched with water that had been spilled from a large ewer that had stood in a bow pon the washstand.

Hastily dressing, I went into the street. The sky above was perfectly clear and the sun was just rising. The air was balmy, and not a breeze stirred the leaves upon the trees. Looking up and down the streets, gray dust could be seen rising, not only from the earth itself, but from the wreckage that strewed th whole city.

I turned the next corner going west, and came sud denly to a large square two-story frame dwelling, that had had its back broken at the second floor joist an had yawed off to one side, the first story meantime half collapsing and the upper story resting upon it intact. Hovering around its portals were some half dozen half-clad, distracted women, and I heard one of them remark that they had all-got out alive, and that there had been eight persons in the house at the time of the hock.

That was a sample of some of the work done in San José. I did not remain to inspect the town, but hurried to the train. When I returned in the evening, friend told me that San José was a wreck. This should be qualified, however. There was hardly a building in town that did not show some effects of the earthquake. Not one chimney in a hundred was standing. The business part had been more badiy damaged than the residence part; hardly a front was intact, while many buildings had entirely collapsed. About thirty persons had been killed, including several entire families.

I took the 6:10 train for San Francisco, and it was a continuous succession of wreckage all the way up the track. There are about a dozen fair-sized towns be tween San José and San Francisco, including Santa Clara, Palo Alto, Redwood City, and San Mateo. Sant Clara was hit fully as hard as San José, but no one was killed. At Palo Alto the buildings of the Leland Stanford, Jr., University were badly wrecked, At Redwood City the new courthouse was about ruined.

Either coming or going I caught glimpses along the principal business streets of these towns, and there were regular windrows of ruins stretching up either side of the streets as

The railroad as far as San Bruno was in fairly good condition, but it must be remembered that it is built over a very low and level tract of country, with no filled grades to speak of. But north of San Bruno there are several arms of the bay marsh lands reaching up into the peninsula, and across these the railroad cómpany was compelled to construct grades that vary from four to ten feet in height above the marsh evel.

Here it was that the earthquake put in some of its heavy licks. The earth embankments were sunk and cracked and the track twisted into serpentine shape for long"distances.

And presently we came to the great cemeteries where the dead of San Francisco have been buried for fifty years. Thousands of headstones and monuments were overturned, and the elaborate gateways wrecked in various ways. Here I had a talk with a railroad employe who lives in the vicinity. He informed me that when the shock came, he was on his way to the small station to draw a pail of water. The motion of the earth was so violent that he was thrown off his balance, and he fell to the ground.

He said, however, that he was not very badly scared until he looked over into the cemeteries, and there
saw "all the gravestones dancing a jig," to use the man's own language.

Now let us refer briefly to the various topographical characteristics of this region: San José stands about midway east and west in the upper end of the Santa Clara Valley. About twelve miles east stands the nner coast range, and about the same distance to the west stands the Santa Cruz or outer coast range. Neither of these ranges was badly shaken. San José stands about ten miles south of the southern extremity of the bay of San Francisco and upon a level plain composed of an alluvial soil.

The peninsular towns mentioned are at about the same level, but the outer coast range swings eastward, so that the valley land narrows down rapidly as one goes north.

The district traversed on the east side of the bay is

also at about the same level, and forms a comparatively narrow strip of land between the bay and the inner coast range.

Some might say that the terrible peninsula was the point of greatest insecurity, but San José, quite a distance south of the base of that arm of land and in the midst of a landlocked valley, got just as bad a shaking as did the peninsula.

\title{
THE ADVANTAGES AND LIMITATIONS OF REINFORCED
} CONCRETE.

A paper read by Mr. Charles S. Hill before the Association of Portland Cement Manufacturers so admirably reviews the merits and defects of reinforced con. crete that it may not be deemed amiss to summarize t here.

The capacity of resistance to tension of concrete, says Mr. Hill, is much less than the ultimate compressive resistance; when a concrete beam, for example, is subjected to transverse loading, it fails by tearing apart on the tension side. The purpose of the combination of concrete and steel known as reinforced concrete is to supply the deficiency of tensile strength in concrete-to make possible the construction of a beam or other member almost entirely of concrete, but which shall, by having imbedded in it steel rods of desired shape and suitable cross-sectional area in proper positions, possess a high capacity to take tensile stresses. The fundamental theory of the combination is that the disposition of the concrete and the steel in the section is such that the two elements act as a single unit, all stresses being divided between the concrete and the steel where the latter occurs.

Actual construction of reinforced concrete 1. lls somewhat short of reaching this theoretical perfection; it is not possible to distribute the steel perfectly through the concrete nor is it possible to secure that absolute adhesion between the concrete and steel which is neces. sary to perfect transmission of the stresses from one material to the other. These defects have to be allowed for in practical design; they may be reduced to quite minute proportions by good design and good workmanship, and they may be so accentuated by poor design and poor workmanship that a weak and dangerous material results.

Premising reasonably good design and workmanship, the claims which reinforced concrete presents as a structural material are sound and important. The compressive resistance of concrete is about ten times its tensile resistance, while steel has about the same strength in tension as in compression. Volume for volume, steel costs about fifty times as much as concrete. For the same sectional areas, steel will support in compression thirty times more load than concrete, and in tension three hundred times the load concrete will carry. Therefore, for duty under compression only, concrete will carry a given load at six-tenths of the cost required to support it with steel. On the other hand, to support a given load by concrete in tension would cost about six times as much as to support it with steel. If, then, the various members of a structure are so designed that all the compression stresses are resisted by concrete and steel is introduced to resist the tensile stresses, each material will be serving the purpose for which it is cheapest and best adapted and one of the principles of economic design will be fulfilled. This is the economic claim which reinforced concrete presents as a structural material.

Other important advantages secured in the combina. tion of concrete and imbedded steel are: that the protection of the metal elements from corrosion is practically perfect; that the fire and heat resisting qualities of a masonry structure are secured at about the cost of a more or less temporary unprotected steel structure. That concrete is an-almost perfect protection of steel from corrosion, is a fact almost beyond reasonable dispute. Both theory and the evidence of actual experience support this statement. It is to be noted, however, that concrete, to be effective in preventing rusting, must be dense, without voids and cracks, and in close contact with the metal at all points. The fire-resisting qualities of concrete have been subjects of much dispute. Theoretically, concrete being a hydrated compound should disintegrate with the expulsion of the water of hydration by heat. Practical ly, however, such disintegration must be very slow because of the high temperature required to drive off the water and because of the poor heat conductivity of the material. To set against whatever weakness concrete may have in the respect mentioned, we have the indisputable evidence that concrete structures hav met the requirements of the most severe municipal 